\title{
Digital-Era Government (DEG): Policy Analysis in Government West Bandung Regency, Indonesia
}

\author{
Engkus
}

UIN Sunan Gunung Djati Bandung Indonesia

engkus@uinsgd.ac.id

\begin{abstract}
The main problem of implementing e-government in West Bandung Regency: technically the website through its features cannot be accessed perfectly; Human resource competence is still limited, and community response is still limited. The purpose of this study is to identify and explain the implementation, barriers and solutions of egovernment. The research method used is a descriptive qualitative approach, with data collection techniques: observation, interviews and documentation study. Data analysis through data collection, data reduction, data display, and matching drawing/verification. This study concludes that the implementation of E-Government in the West Bandung district has not been optimal, so researchers recommend improving website infrastructure, increasing technical competence of human resources, as well as increasing socialization through innovation in various spaces including through public service advertisements \& media platforms, education and mentoring to the community.
\end{abstract}

Keywords: digital-era government, policy implementation, human resource competence

\section{INTRODUCTION}

In September 2005, the world of bureaucracy was shocked by the emergence of a new idea published in an article entitled New Public Management Is Dead - Long Live Digital-Era Governance in the journal of Public Administration Research and Theory by Patrick Dunleavy et al. [1]. The three main ideas expressed are known as 3 Orientations for Digital-Era Governance (DEG): (1) Reintegration: Reintegration of the administration of government affairs. (2) Needs-based holism: Rearrange the structure of public organizations with holistic and needs-oriented principles. (3) Digitization changes: Complete digitization of conventional administrative processes and business processes, they become truly transformative, moving towards a situation where the agency/institution "becomes its Web site". The development of information and communication technology nowadays offers so many solutions in an effort to improve the performance of public services that are more based on good governance (good governance). The readiness of human resources, budget funds, regulations and facilities and infrastructure are absolute things that must be provided in the implementation of EGovernment (Nugraha, 2018) [2]. E-Government in
Indonesia has been introduced since 2001 through Presidential Instruction No. 6 of 2001 on Telematics (Telecommunications, Media and Informatics) which states that government officials must use telematics technology to support good governance and accelerate the democratic process. [3] Then the issuance of Presidential Instruction of the Republic of Indonesia Number 3 of 2003 concerning National Policy and Strategy for E-Government Development. [4] The two Presidential Instruction is a serious step by the Government of Indonesia to utilize information and communication technology in the government process and create an Indonesian government based on information technology.

One of the local governments that has begun to implement the concept of E-Government is the West Bandung Regency Government, which is one of its efforts to create an official website for West Bandung Regency which is managed and under the responsibility of the Office of Communication, Informatics and Statistics of West Bandung Regency with a legal basis: Provincial Regulations West Java Number 29 of 2010 concerning the Implementation of Communication and Information Technology, as well as West Bandung Regent Regulation Number 9 of 2017 concerning Electronic-Based Government Development in Local Government Environments [5]. 
The official website of West Bandung Regency presents several features related to all West Bandung Regency Government information, including information about West Bandung, public services, public complaints, government applications, planning documents, budget management transparency and so on.

Based on the results of an interview with one of the staff of the West Bandung Regency Information and Information Communication Office and from the results of the analysis of the researcher as a visitor to the West Bandung Regency Official website from 2017, the researcher found several obstacles from the implementation of the official website of West Bandung Regency, including the web that cannot be accessed. perfect where there are some features that cannot be accessed, the news or information from the Regional Apparatus is still not up to date, there is no addition of more interactive features, many human resources deployed are still not in accordance with competency standards which is needed, and there is still a lack of public participation in visiting this website where many people of West Bandung Regency do not even know about the implementation of the official website of the West Bandung Regency Government.

In explaining the implementation of egovernment in West Bandung Regency government, this study uses the theory of indicators of successful policy implementation from Van Meter and Van Horn (1975) which include: 1.) policy standards and objectives; 2.) resources; 3 .) communication between organizations and strengthening activities; 4.) the characteristics of the executing agent; 5.) social, economic and political environment. 6.) implementor disposition [6].

\section{RESEARCH METHOD}

This study uses a qualitative research method with a descriptive approach in which data is collected in the form of words, not numbers [7]. This study describes the extent to which the successful implementation of E-Government in the West Bandung Regency government. [8] Data collection techniques used: observation, interviews, and literature study. By digging information in depth [9] through 7 research informants [10], consisting of 1 key informant; 2 main informants, and 4 supporting informants.

\section{RESULTS AND DISCUSSION}

Implementation of E-Government in West Bandung Regency Government, in order to find out how E-Government Implementation in West Bandung Regency Government with a case study of Implementation of the Official Website of West Bandung Regency, if associated with the theory of policy implementation from Van Meter and Van Horn in Winarno (2016). [11], wherein this theory there are six dimensions, namely standards and policy objectives, communication between organizations and strengthening activities, characteristics of the implementing agency, social, economic and political conditions, and the disposition of implementers, [12] the six dimensions play a very important role and support the successful implementation of a policy. Therefore, in the process of implementing egovernment in the West Bandung Regency Government, the dimensions of Van Meter and Van Horn are reviewed as follows: (a) Policy standards and targets, Implementation of the application of the official website of West Bandung Regency cannot guarantee that it has been achieved accordingly. With predetermined standards and targets, the targets that have been achieved are only in the realm of government and regional apparatus, while the targets aimed at the community have not been fully achieved because of the vast area of West Bandung Regency which has many villages. This is in accordance with the results of the researcher interview. (b) Resources, in Department of Communication, Information and Statistics there are not sufficient needs, including the need for managing the official website of West Bandung Regency. Meanwhile, in terms of financial resources, it is still not able to meet the needs of implementing a website which could become an obstacle to the development of the website of the West Bandung Regency government. However, in this case, the researcher cannot present detailed data on financial needs due to certain factors. (c) Communication between organizations and strengthening activities can be said to have been well established and strived to be continuously improved. However, for communication with the community as one of the targets of the implementation of the official website of West Bandung Regency, it can be said that it is not effective enough so that there are still people who do not know the website and do not even know its function [13]. [14] Furthermore, with regard to communication between organizations and between employees, there are other supporting indicators, namely strengthening of implementing activities which is crucial. There are two types of implementation activities that can be carried out, namely: First, in the form of providing 
advice, direction and technical assistance from superiors and colleagues. Second, in the form of imposing both positive and negative sanctions from superiors if they find an employee committing a violation in policy implementation. In terms of strengthening the activities carried out, there is only no technical assistance, while the provision of advice, direction, and sanctions have been implemented, including giving awards to exemplary employees. (d) Characteristics of implementing agents, already running. However, according to the observations of researchers as website users, even though the organizational structure and employee competencies are said to be good, but in terms of performance, the implementation of the West Bandung Regency government website is still not perfect, the information presented is not updated quickly, [15] such as when changing the staffing structure of a certain Office, the staffing structure information that was previously presented on the web has not been changed quickly. So, the researchers concluded that the standard competency of employees in managing the West Bandung Regency government website is still not fast and responsive, possibly because there is still a lack of the number of employees needed. Meanwhile, regarding political sources in the form of support from the legislative and executive bodies, support from the legislative and executive parties has synergized well, between the executive and legislative parties it can be said that they have established a harmonious relationship with the implementing body, in this case, the Department of Communication, Information and Statistics, West Bandung Regency as the manager of the West Bandung Regency government website. (e) Social, economic and political conditions are some of the instruments in the social environment which certainly have an important influence on the implementation of public policy [16]. In this study, the community has a big role in the implementation of e-government in the application of the website of West Bandung Regency where the community is one of the targets of the implementation [17]. For this reason, the West Bandung District Office of Communication and Information as of the manager always tries to socialize [18] related websites to the public. Apart from social conditions, economic and political conditions also have a major influence on the successful implementation of the official website of West Bandung Regency. (f) Implementor disposition, there is no problem in employee understanding of the policy of implementing the website of the West Bandung Regency government, besides that there is also no rejection of the application of the West Bandung Regency website from the policy implementer, from the leadership to the employees who run the website implementation. the official government of West Bandung Regency.

(2) Obstacles in the Implementation of E-Government in the West Bandung Regency Government, which occurred in the implementation of e-government of the West Bandung Regency government in implementing the official website of West Bandung Regency, including the difficulty of reaching all people in order to have accessibility in the use of information technology[19], and the lack of public knowledge about the use of the website of West Bandung Regency. Another obstacle in implementing the website of the West Bandung Regency government is that it comes from human and financial resources that are not sufficient for the application of the website. In addition to these obstacles, according to researchers another obstacle in the successful implementation of the West Bandung Regency website is the lack of socialization [20] from the government to the public about the existence of the West Bandung Regency website, so there is still no knowledge of the West Bandung Regency government website. (3) Solutions to Overcome Barriers to E-Government Implementation in West Bandung Regency Government. In addition to the obstacles that occur in the process of implementing public policies, of course, there need to be solutions to overcome these obstacles [21]. Based on the results of the interview, the West Bandung Regency Office of Communication and Information itself has tried to continue to make improvements in the management of the website of the West Bandung Regency government. However, from the results of the interview, it was not explained in detail what solutions had been carried out by the relevant agencies to overcome obstacles in the implementation of the West Bandung Regency government website. Thus, the researcher adds solutions that can be done to overcome the obstacles that occur in the process of implementing the egovernment application of the West Bandung Regency government website based on the researcher's analysis and based on community input from the results of interviews, including (a) Conducting wider outreach, especially to rural communities about the West Bandung Regency Government Website; (b) Adding more competent personnel in the field of Information Technology, especially in managing the Website. (c) Proposing a large enough budget to the Central Government to meet the needs of implementing egovernment implementing the website of the West Bandung Regency government. 


\section{CONCLUSION}

Implementation of E-Government in West Bandung Regency Government has been running, but not optimal. Analyzed from the dimensions of standards and policy objectives for the implementation of the official website of West Bandung Regency has not been achieved according to the standards and targets that have been formulated, as evidenced by the fact that there are still people who do not know the official website of West Bandung Regency.

The obstacles faced in implementing egovernment in the West Bandung Regency government are that internet network access has not yet reached all communities, especially rural communities, community knowledge of the official website of West Bandung Regency is still lacking, and there is still a lack of human resources and resources. financial resources to meet the management needs of the official website of West Bandung Regency.

Thus the researchers recommend overcoming the obstacles that occur in the implementation of egovernment in West Bandung Regency including carrying out wider socialization, increasing the number of employees of the West Bandung Regency Office of Communication and Information, and proposing a larger budget for the management of the official website of West Bandung Regency.

\section{REFERENCES}

[1] Dunleavy et_al. (2005). New Public Management Is Dead-Long Live Digital-Era

Governance. Journal of Public Administration Research and Theory. 16: 467-494.

[2] Nugraha, J. T. (2018). E-Government Dan Pelayanan Publik E-Government Di Pemerintah Kabupaten Sleman ). Jurnal Komunikasi Dan Kajian Media, 2(1), 32-42.

[3] Instruksi Presiden Pepublik Indonesia Nomor 6 Tahun 2001 Tentang Pengembangan Dan Pendayagunaan Telematika Di Indonesia. Presiden Indonesia.24 April.

[4] Instruksi Presiden Pepublik Indonesia Nomor 3 Tahun 2003 Tentang Kebijakan dan Strategi Nasional Pengembangan E-Government. Presiden Indonesia.9 Juni.

[5] Peraturan Daerah Provinsi Jawa Barat Nomor 29 Tahun 2010 Tentang Penyelengaran
Komuniksi Dan Informatika. Gubernur Jawa Barat.31 Desember.

[6] Peraturan Bupati Bandung Barat nomor 9 Tahun 2010 Tentang Pengembangan Pemerintahan

Berbasis Elektronik Di LingkunganPemerintah Daerah. Bupati Bandung Barat. 29

Maret.

[7] Sugiyono. (2016). Metode Penelitian Administrasi. Bandung: Alfabeta.

[8] Silalahi, U. (2017). Metode Penelitian Sosial Kuantitatif. Bandung: PT Refika Aditama.

[9] Moleong, L. J. (2013). Metodologi Penelitian Kualitatif. Bandung: PT. Remaja Rosdakarya.

[10] Sugiyono. (2012). Metode Penelitian Kombinasi. Bandung: Alfabeta.

[11] Winarno, B. (2016). Kebijakan Publik Teori dan Proses. Yogyakarta: Media Pressindo.

[12] Subarsono. (2011). Analisis Kebijakan Publik. Yogyakarta: Pustaka Pelajar.

[13] Nugraha, J. T. (2018). E-Government Dan Pelayanan Publik E-Government Di Pemerintah.

[14] Engkus, E. (2020). Komunikasi Kebijakan Bantuan Pangan Nontunai melalui E-Warong. Jurnal Penelitian Komunikasi, 23(1),47-60.

[15] Mulyadi, D. (2016). Studi Kebijakan Publik dan Pelayanan Publik (Konsep dan Aplikasi Proses Kebijakan Publik Berbasis Analisis Bukti untuk Pelayanan Publik). Bandung: Alfabeta

[16] Nugroho, R. (2015). Kebijakan Publik Di Negara-Negara Berkembang. Yogyakarta: Pustaka Pelajar.

[17] Indrajit, R. E. (2006). Electronic Government (Strategi Pembangunan dan Pengembangan Sistem Pelayanan Publik Berbasis Teknologi Digital). Yogyakarta: Andi Offset.

[18] Syafri, Wirman \& Setyoko, I. (2010). Implementasi Kebijakan Publik dan Etika Profesi Pamong Praja. Bandung: Alqaprint.

[19] Agustino, L. (2014). Dasar-Dasar Kebijakan Publik. Bandung: Alfabeta.

[20] Abidin, Z. S. (2004). Kebijakan Publik. Jakarta: Yayasan Pancur Simbah.

[21] Muis, I., Nurdin, I., Erlangga, H., \& Engkus, E. (2019). Post Disaster Social Vulnerability:

Policy Analysis and Implementation in Communities in Indonesia. Journal of Critical Reviews, 6(5), 59-66. 